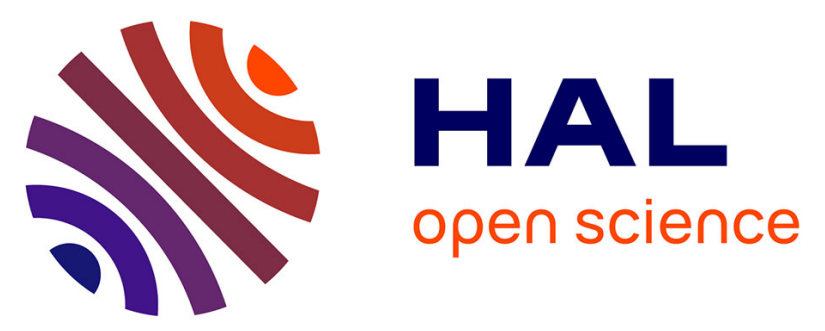

\title{
Altered serum levels of human neutrophil peptides (HNP) and human beta-defensin 2 (hBD2) in Wegener's granulomatosis
}

Stefan Vordenbäumen, Daniel Timm, Ellen Bleck, Jutta Richter, Rebecca Fischer-Betz, Gamal Chehab, Oliver Sander, Matthias Schneider

\section{- To cite this version:}

Stefan Vordenbäumen, Daniel Timm, Ellen Bleck, Jutta Richter, Rebecca Fischer-Betz, et al.. Altered serum levels of human neutrophil peptides (HNP) and human beta-defensin 2 (hBD2) in Wegener's granulomatosis. Rheumatology International, 2010, 31 (9), pp.1251-1254. 10.1007/s00296-010-17020. hal-00647969

\section{HAL Id: hal-00647969 \\ https://hal.science/hal-00647969}

Submitted on 4 Dec 2011

HAL is a multi-disciplinary open access archive for the deposit and dissemination of scientific research documents, whether they are published or not. The documents may come from teaching and research institutions in France or abroad, or from public or private research centers.
L'archive ouverte pluridisciplinaire HAL, est destinée au dépôt et à la diffusion de documents scientifiques de niveau recherche, publiés ou non, émanant des établissements d'enseignement et de recherche français ou étrangers, des laboratoires publics ou privés. 


\section{Altered serum levels of human neutrophil peptides (HNP) and human beta-defensin 2 (hBD2) in Wegener's Granulomatosis}

Stefan Vordenbäumen $\mathrm{MD}^{1}$, Daniel Timm ${ }^{1}$, Ellen Bleck ${ }^{1}$, Jutta Richter $\mathrm{MD}^{1}$, Rebecca Fischer-Betz MD ${ }^{1}$, Gamal Chehab MD ${ }^{1}$, Oliver Sander MD ${ }^{1}$, Matthias Schneider MD $\mathrm{PhD}^{1}$

1 Department of Endocrinology, Diabetology, and Rheumatology, Heinrich Heine University, Moorenstr. 5, 40225 Düsseldorf, Germany

\section{Address of correspondence}

Dr. Stefan Vordenbäumen

Section of Rheumatology

Department of Endocrinology, Diabetology and Rheumatology

University Hospital Düsseldorf

Moorenstr. 5

40225 Düsseldorf

Germany

Tel.: $\quad$ 0049-(0)211-811-7817

Fax: $\quad$ 0049-(0)211-811-6455

e-mail: $\quad$ Stefan.Vordenbaeumen@med.uni-duesseldorf.de

competing interest: none

financial support information: this work was supported by an unconditional grant form the "Hiller-Stiftung"

word count: 1151 


\section{Abstract}

Defensins are highly conserved peptides with antimicrobial and immunomodulatory functions. Due to their chemotactic properties on mononuclear cells, including dendritic cells and macrophages, defensins may contribute to granuloma formation in Wegener's granulomatosis (WG). In order to explore if these peptides might be involved in WG pathogenesis, sera of patients were screened to detect altered defensin-levels. For this purpose, serum and EDTA-blood of patients with WG ( $\mathrm{n}=$ 17 ; aged $54.8 \pm 15.5$ years) and age- and sex-matched healthy controls $(n=24$; aged $55.5 \pm 16.8$ years) were collected. Levels of neutrophil alpha-defensins (human neutrophi peptides, HNP) and beta-defensin (hBD) 2 and 3 in serum were measured by ELISA. By this means, WG patients displayed higher serum levels of hBD2 and HNP when compared to controls. Furthermore, serum hBD2 was raised in patients with meningeal granulomas $(n=4)$ or in those undergoing treatment with cyclophosphamide $(n=4)$. In order to detect if increased gene-expression in polymorphonuclear cells is responsible for the elevated defensin-levels, real-time polymerase-chain-reaction with gene-specific primers was performed. Expression of specific mRNA in polymorphonuclear cells was observed for HNP only, but did not parallel HNP serum levels, suggesting that degranulation rather than increased geneexpression may be responsible for increased HNP-serum levels in WG. In conclusion, elevated serum levels of HNP and hBD2 in WG patients suggest a role for both defensins in WG pathogenesis.

Key words: human neutrophil peptide, innate immunity, alpha-defensin, betadefensin, antimicrobial peptides, Wegener Granulomatosis 


\section{Introduction}

Defensins initially attracted interest due to their potent antimicrobial functions and highly conserved structure [1]. Consequently, several immunomodulatory functions like chemotactic effects and the ability to induce the production of cytokines have been identified [2,3], suggesting that these peptides connect innate and adaptive immune-responses [2]. Their importance for autoimmune disorders is supported by the recent finding of modulated defensin expression in patients with systemic lupus erythematosus $[4,5]$. Human neutrophil peptides (HNP) stem from the neutrophil granula of leukocytes [6], while other structurally similar alpha-defensins are mainly expressed in the small intestine [7,8]. Amongst the beta-defensins (hBD), distinguished from alpha-defensins by diverse disulfid bonding, hBD 2 and 3 are upregulated in response to inflammatory stimuli [9-11] and are secreted by some epithelial surfaces and blood cells [12,13].

Wegener granulomatosis (WG) is characterized by a granulomatous inflammation with various degrees of vasculitis leading to tissue necrosis with a predilection for the respiratory tract and the kidneys [14]. Antineutrophil cytoplasmatic antibodies (ANCA) directed against proteinase 3 are strongly associated with WG [15] and have been implicated in the pathogenesis of the disease [16]. They activate neutrophil granulocytes and induce the release of HNP from neutrophils [17]. By the ability to chemoattract monocytes, macrophages, dendritic cells, and T cells [6,18], defensins may contribute to granuloma formation in WG [17]. However, reports about defensinserum levels in WG patients are lacking. Therefore, our objective was to evaluate the serum level and expression of HNP, hBD2, and hBD3 in WG patients to further explore if defensins might play a role in WG pathogenesis.

\section{Materials and Methods}

\section{Patients and samples}

Patients were diagnosed according to ACR criteria [19]. In all consecutive patients, total blood count, creatinine, c-reactive protein (CRP), and ANCA-staining were routinely performed; current and past medication as well as disease manifestations were recorded. Patients were excluded if the presence of infection could not be 
excluded based on history, physical examination, and urine analysis. Disease activity was determined by the Birmingham Vasculitis Activity Score (BVAS). For performance of defensin-ELISA, $10 \mathrm{ml}$ of Serum was collected from patients and healthy volunteers and frozen to $-20^{\circ} \mathrm{C}$ prior to the assay. For PCR-analysis, $10 \mathrm{ml}$ EDTA blood was obtained and processed within 2 hours. All patients and volunteers gave their full consent. The study was approved by the local ethics committee.

\section{Enzyme-linked immunosorbent assay (ELISA)}

Human HNP1-3 ELISA Test Kit (Hycult biotechnology, Uden, The Netherlands) and human $\beta$-Defensin 2 and 3 ELISA Kit (Phoenix Pharmaceuticals, Burlingame, California, USA) were applied for measurement of HNP and hBD2 and 3 respectively according to the manufacturer's instructions. Briefly, serum was diluted 1:2000 in dilution buffer for HNP, 1:100 fo hBD2 and undiluted for hBD3 prior to transferring duplicate samples to microtitre plates and initiation of recommended incubation procedures. Absorbance was measured at 450nm using the Anthos 2001 ELISAreader (anthos Mikrosysteme, Krefeld, Germany).

\section{Semi-quantitative real-time Polymerase chain reaction (rtPCR)}

Polymorphonuclear cells (PMN) were isolated from EDTA-blood using Polymorphprep (Axis-Shield, Oslo, Norway), mRNA was isolated with Rneasy Mini Kit (Qiagen, Hilden, Germany), and reverse transcription was performed using QantiTect Reverse Transcription (Qiagen) according to the manufacturer's instructions. Polymerase-chain-reaction $(\mathrm{PCR})$ with real time measurement of fluorescence was carried out on the 7300 Real-time PCR system (Applied Biosystems, Foster City, CA, USA) with $0.3 \mu \mathrm{M}$ gene-specific, exon-spanning primers for HNP (fw: 5' ${ }^{\circ}$-TCCCAGAAGTGGTTGTTTCC-3', rv: 5'GCAGAATGCCCAGAGTCTTC-3`), hBD2 (fw: 5‘-TGATGCCTCTTCCAGGTGTTT-3،, rv: 5'-GGATGACATATGGCTCCACTCTT-3'), and hBD3 (fw: 5' CTGTTTTTGGTGCCTGTTCC-3،, rv: 5'-CTTTCTTCGGCAGCATTTTC-3') in duplicate using Qantitect SYBR green PCR Kit (Qiagen). Results were relatively quantified using glyceraldehyde 3 phosphate dehydrogenase (fw: 3 CCAGCCGAGCCACATCGCTC-5', rv: 5'-ATGAGCCCCAGCCTTCTCCAT-3') as internal and reference RNA (Stratagene, La Jolla, CA, USA) as external standard according to the $-\triangle \Delta C T$-method. 


\section{Statistical analysis}

Data comparison was carried out using Mann-Whitney-U test. For comparison of continuous variables, two-tailed bivariate correlations and Pearson's coefficient were calculated. P-values $<0.05$ were considered significant.

\section{Results}

\section{Patient characteristics}

17 consecutive patients with WG were aged $54.8 \pm 15.5$ years (mean \pm SD; $47.1 \%$ female). Healthy controls $(n=24)$ were aged $55.5 \pm 16.8$ years (mean \pm SD; $50 \%$ female). There were no correlations of measured parameters to sex, age, laboratory values or BVAS. Diseases extend, laboratory values, and treatment at the time of the study are summarized in table 1 .

\section{Defensin measurements}

In order to determine serum levels of defensins, ELISA for hBD2, hBD3 and HNP were performed on samples of patients and healthy controls. HBD2 and HNP, but not hBD3, were elevated in patients with WG as opposed to healthy controls (figure 1). To determine if defensin-levels varied with respect to the disease state, serum levels were compared to clinical data and laboratory values. Thereby, hBD2 was found to be higher in patients with meningeal involvement ( $n=4$; figure 2), evidenced by the presence of proliferations on magnetic resonance imaging. Furthermore, patients undergoing treatment with cyclophosphamide displayed superior levels of serum HNP ( $n=4$; figure 2). Next, we assessed whether PMN could be the source of defensins in WG patients. For this purpose, we performed real-time PCR with gene specific primers for the defensins studied. Only HNP-mRNA was detectable, but did not parallel serum HNP measurements. Values between patients and controls were rather equal. 


\section{Discussion}

ANCA-mediated release of $\alpha$-defensins might contribute to granuloma-formation due to chemotactic properties on monocytes, macrophages, dendritic cells, and $T$ cells $[6,17]$. Similarly, hBD2 and 3 chemoattract macrophages and monocytes [18]. Interestingly, high $\alpha$-defensin-levels have been reported in the bronchoalveolar lavage fluid and plasma of one WG patient previously [20]. Furthermore, other vasculitic diseases, like microscopic polyangiitis [21] and cutaneous vasculitis [22] were associated to increased $\alpha$-defensins and hBD2 expression respectively. The present study demonstrates elevated serum values of HNP and hBD2 in WG patients when compared to healthy controls. Meningeal granulomas and cyclophosphamid treatment, which might be found more frequently in sicker patients, were associated with modulated hBD2 and HNP serum levels respectively. Although hampered by the small patient number, these findings support the notion that defensins might be involved in WG pathogenesis and are an interesting target for future research as novel therapeutic options may arise.

Neutrophile granula of leukocytes are the main source of human neutrophile peptides ( $\alpha$-defensin 1-4) [6]. Interestingly, no correlation of HNP serum levels to the leukocyte count or to HNP-mRNA copy-numbers were found. Thus, we speculate that degranulation of neutrophile granulocytes rather than increased neutrophile numbers or increased HNP-gene-expression is responsible for elevated $\alpha$-defensin levels in WG patients. Beta-defensins are expressed in various tissues which might contribute to beta-defensin serum levels [1]. Based on our observations, PMN are unlikely to be responsible for beta-defensin production, because no specific mRNA was found.

Although the study served to address our objectives, the small patient number and relatively high standard deviations may be regarded as drawbacks to this study.

\section{Conclusions}

To the best of our knowledge, this is the first study to systematically evaluate serum defensin-levels in WG. Our results further implicate a role for HNP and hBD2 in WG pathogenesis. Additional studies in this interesting field are needed. 


\section{References}

1. Schneider JJ, Unholzer A, Schaller M, Schäfer-Korting M, Korting HC (2005) Human defensins. J Mol Med 83:587-595

2. Yang D, Chertov O, Bykoskaia SN, Chen Q, Buffo MJ, Shogan J, Anderson M, Schröder J-M, Wang JM, Howard OMZ, Oppenheim JJ (1999) Beta-defensins: Linking innate and adaptive immunity through dendritic and t cell ccr6. Science 286:525-528

3. Yang D, Biragyn A, Hoover DM, Lubkowski J, Oppenheim JJ (2004) Multiple roles of antimicrobial defensins, cathelicidins, and eosionphil-derived neurotoxin in host defence. Annu Rev Immunol 22:181-215

4. Sthoeger ZM, Bezalel S, Chapnik N, Asher I, Froy O (2009) High alphadefensin levels in patients with systemic lupus erythematosus. Immunology 127:116-122

5. Vordenbäumen S, Fischer-Betz R, Timm D, Sander O, Chehab G, Richter J, Bleck E, Schneider M (2010) Elevated levels of human beta-defensin 2 (hbd2) and human neutrophil peptides (hnp) in systemic lupus erythematosus. Lupus in press

6. Rehaume LM, Hancock RE (2008) Neutrophil-derived defensins as modulators of innate immune function. Crit Rev Immunol 28:185-200

7. Mallow EB, Harris A, Salzman A, Russel JP, DeBerardinis RJ, Ruchelli E, Bevins CL (1996) Human enteric defensins. J Biol Chem 271:4038-4045

8. Vordenbäumen S, Pilic D, Otte J-M, Schmitz F, Schmidt-Choudhury A (2009) Defensins are differentially expressed with respect to the anatomic region in the upper gastrointestinal tract of children. J Pediatr Gastroenterol Nutr 49:139-142

9. Becker MN, Diamond G, Verghese MW, Randell SH (2000) Cd14-dependent lipopolysaccharide-induced beta-defensin-2 expression in human tracheobronchial epithelium. J Biol Chem 275:29731-29736

10. Fahlgren A, Hammarstrom S, Danielsson A, Hammarstom ML (2004) Betadefensin-3 and -4 in intestinal epithelial cells display increased mrna expression in ulcerative colitis. Clin Exp Immunol 137:379-385

11. Vordenbäumen S, Pilic D, Otte J-M, Schmitz F, Schmidt-Choudhury A (2010) Defensin-mrna-expression in the upper gastrointestinal tract is modulated in 
celiac disease and helicobacter-pylori -positive children. J Pediatr Gastroenterol Nutr 50:596-600

12. Zhang L, Yu W, He T, Yu J, Caffrey RE, Dalmasso EA, Fu S, Pham T, Mei J, Ho JJ, Zhang W, Lopez P, Ho DD (2002) Contribution of human alphadefensins 1,2 , and 3 to the anti-hiv-activity of cd8 antiviral factor. Science 298:995-1000

13. Duits LA, Ravensbergen B, Rademaker M, Hiemstra PS, Nibbering PH (2002) Expression of beta-defensin 1 and 2 mrna by human monocytes, macrophages and dendritic cells. Immunology 106:517-525

14. Moosig F, Lamprecht P, Gross WL (2008) Wegener's granulomatosis: The current view. Clin Rev Allergy Immunol 35:19-21

15. Hagen EC, Daha MR, Hermans J, Andrassy K, Csernok E, Gaskin G, Lesavere P, Lüdemann J, Rasmussen N, Sinicio RA, Wiik A, van der Woude FJ (1998) Diagnostic value of standardized assays for anti-neutrophil cytoplasmic antibodies in idiopathic systemic vasculitis. Kidney Int 53:743-753

16. Csernok E, Moosig F, Gross WL (2008) Pathways to anca production: From differentiation of dendritic cells by proteinase 3 to $b$ lymphocyte maturation in wegener's granuloma. Clin Rev Allergy Immunol 34:300-306

17. Tanaka S, Edberg JC, Chatham W, Fassina G, Kimberly RP (2003) Fc(gamma)riiib allele-sensitive release of alpha-defensins: Anti-neutrophile cytoplasmic antibody-induced release of chemotaxins. J Immunol 171:60906096

18. Röhrl J, Yang D, Oppenheim JJ, Hehlgans T (2010) Human b-defensin 2 and 3 and their mouse orthologs induce chemotaxis through interaction with ccr2. J Immunol 184:6688-6694

19. Leavitt RY, Fauci AS, Bloch DA, Michel BA, Hunder GC, Arend WP, Calabrese LH, Fries JF, Lie JT, Lightfoot RWj (1990) The american college of rheumatology 1990 criteria for the classification of wegner's granulomatosis. Arthritis Rheum 33:1101-1107

20. Mukae H, Matsumoto N, Ashitani J, Mahimoto H, Kadota J, Nakazato M, Kohno S, Matsukura S (1996) Neutrophil-related cytokines and neutrophil products in bronchoalveolar lavage fluid Eur Respir J 9:1950-1954 
21. Tamiya H, Tani K, Miyata J, Sato K, Urata T, Lkhagvaa B, Otsuka S, Shigekiyo S, Sone S (2006) Defensin- and cathepsin g-anca in systemic lupus erythematosus. Rheumatol Int 27:147-152

22. Srivastava MD, Alexander F, Tuthill RJ (2005) Immunology of cutaneous vasculitis associated with both etanercept and infliximab. Scand J Immunol 61:329-336 
Table 1 - Patient characteristics

\section{Patient characteristics}

\begin{tabular}{|c|c|}
\hline $\begin{array}{l}\text { number } \\
\text { age (years } \pm \text { SD) } \\
\text { \%female }\end{array}$ & $\begin{array}{l}17 \\
54.8 \pm 15.5 \\
47.1\end{array}$ \\
\hline \multicolumn{2}{|c|}{ Laboratory values (mean \pm SD) } \\
\hline $\mathrm{RBC}(/ \mu \mathrm{l})$ & $4,3 \pm 0,7$ \\
\hline WBC $(/ \mu \mathrm{l})$ & $8.5 \pm 4.4$ \\
\hline thrombocytes/ $\mu \mathrm{l}$ & $278,471 \pm 101$ \\
\hline $\operatorname{CRP}(\mathrm{mg} / \mathrm{dl})$ & $1.6 \pm 1.9$ \\
\hline creatinine $(\mathrm{mg} / \mathrm{dl})$ & $1.5 \pm 1.0$ \\
\hline PR3-ELISA (U/I) & $90.36 \pm 100$ \\
\hline
\end{tabular}

Disease activity parameters (mean \pm SD)

BVAS $12.6 \pm 14.6$

\begin{tabular}{|c|c|c|}
\hline \multicolumn{3}{|c|}{ Organ involvement (n (\%)) } \\
\hline renal & $8(47.1)$ & \\
\hline upper airway & $9(52.9)$ & \\
\hline lower airway & $5(29.4)$ & \\
\hline eyes & $1(5.9)$ & \\
\hline meningeal & $4(23.5)$ & $\mathrm{p}<.05$ serum $\mathrm{hBD} 2$ \\
\hline peripheral nerves & $2(11.8)$ & \\
\hline Treatment (n (\%)) & & \\
\hline glucocorticoids & $11(64.7)$ & \\
\hline methotrexate & $3(17.6)$ & \\
\hline azathioprine & $7(41.2)$ & \\
\hline anti-TNF $\alpha$ & $2(11.8)$ & \\
\hline rituximab & $1(5.9)$ & \\
\hline cyclophosphamide & $4(23.5)$ & $\mathrm{p}<.05$ serum HNP \\
\hline
\end{tabular}

Characteristics, laboratory values, disease extend and treatment of patients with Wegener granulomatosis. Organ involvement was defined according to ACR criteria. RBC: red blood cell count; WBC: white blood cell count; CRP: c-reactive-protein. PR3-ELISA: Proteinase3 Enzyme-linked immunosorbent assay; BVAS: Birmingham Vasculitis Activitiy Score; meningeal: meningeal involvement as defined by magnetic resonance imaging; significant differences determined by Mann-Whitney-U test are marked. 


\section{Legends for illustrations}

Fig. 1 Serum levels of human $\beta$-defensin 2 (hBD2) and human neutrophil peptides (HNP) in patients with Wegener's granulomatosis (WG; $n=17$ ) and healthy controls $(n=24)$. Significant differences as determined by Mann-Whitney-U test $(p<.05)$ are indicated $\left(^{*}\right)$.

Fig. 2 a) Serum levels of human $\beta$-defensin $2(h B D 2)$ in patients with $(n=4)$ or without $(n=13)$ meningeal proliferations demonstrated by magnetic resonance imaging in patients with Wegener's granulomatosis. b) Serum levels of human neutrophil peptides (HNP) in patients undergoing treatment with cyclophosphamide $(C Y C ; n=4)$ compared to those without (no CYC). Significant results as determined by Mann-Whitney-U test are indicated. 